\title{
ANALISIS PENGARUH PROFITABILITAS, LEVERAGE, DAN LIKUIDITAS TERHADAP FINANCIAL DISTRESS
}

\author{
Ayumi Rahma \\ Universitas Pamulang \\ ayumirahma2004@gmail.com
}

\begin{abstract}
Financial distress occurs before bankruptcy. This condition needs to be detected early so that corrective actions can be taken and bankruptcy can be avoided. Financial ratios are commonly used to detect financial distress early. Those ratios are profitability, leverage, and liquidity. This study aims to analize the impact of profitability, leverage and liquidity on financial distress. The population of this study is transportation company listed on Indonesia Stock Exchange from 2014 to 2019. Purposive sampling is used as a method in samples selection. Logit regression is used to analize the effect profitability, leverage, and liquidity on financial distress. This study finds that profitability and leverage has negative effect on financial distress. On the other hand, this study finds that liquidity has no effect on financial distress.
\end{abstract}

Keywords: Financial Distress; Profitability; Leverage; Liquidity; Logit Regression

\begin{abstract}
Abstrak
Financial Distress merupakan suatu kondisi yang terjadi sebelum kebangkrutan. Kondisi ini perlu diketahui sejak dini agar tindakan-tindakan perbaikan dapat diambil sehingga kebangkrutan bisa dihindari. Salah satu cara untuk dapat mendeteksi financial distress adalah dengan menggunakan rasio keuangan seperti profitabilitas, leverage dan likuiditas. Untuk itu, penelitian ini bertujuan untuk menguji secara empiris pengaruh profitabilitas, leverage dan likuiditas terhadap financial distress. Penelitian ini menggunakan perusahaan yang terdaftar pada sub sektor transportasi yang terdaftar di Bursa Efek Indonesia periode 2014-2019. Teknik pengambilan sampel yang digunakan adalah purposive sampling. Pengujian hipotesis dilakukan dengan menggunakan regresi logistik. Hasil pengujian dalam penelitian ini adalah profitabilitas dan leverage memiliki pengaruh negatif terhadap financial distress. Di sisi lain, likuiditas tidak terbukti memiliki pengaruh yang signifikan terhadap financial distress.
\end{abstract}

Kata Kunci: Financial Distress; Profitabilitas; Leverage; Likuiditas; Regresi Logistik

* Corresponding author's e-mail: ayumirahma2004@gmail.com

http://openjournal.unpam.ac.id/index.php/JABI 


\section{PENDAHULUAN}

Sepanjang tahun 2017 terdapat delapan perusahaan yang sahamnya delisting dari Bursa Efek Indonesia (BEI). Selanjutnya, pada tahun 2018 tercatat ada empat perusahaan yang harus delisting dari lantai bursa dan di tahun 2019 terdapat enam perusahaan yang harus mengalami delisting. Beberapa diantaranya berupa delisting paksa atau force delisting. Force delisting biasanya dilakukan ketika kelangsungan usaha (going concern) suatu emiten terganggu. Kelangsungan usaha ini berkaitan erat dengan kinerja perusahaan. Kinerja yang buruk dapat membawa suatu perusahaan berada dalam kondisi yang dinamakan sebagai financial distress.

Menurut Hapsari (2012) financial distress merupakan suatu kondisi di mana keuangan perusahaan berada dalam krisis dan terjadi sebelum kebangkrutan. Lebih lanjut Hapsari (2012) mengatakan bahwa kondisi ini terjadi ketika suatu perusahaan mengalami kerugian selama beberapa tahun. Kebangkrutan dapat dihindari jika perusahaan mampu memprediksi terjadinya financial distress sejak dini sehingga manajemen dapat melakukan tindakan-tindakan yang diperlukan untuk memperbaiki kondisi perusahaan. Widyasaputri (2012) mengatakan perusahan dengan kondisi laba yang cenderung menurun biasanya akan semakin sulit dan akan mengalami kebangkrutan perusahaan atau likuidasi.

Untuk mengetahui kondisi keuangan suatu perusahaan, maka analisis terhadap laporan keuangan perlu dilakukan. Salah satu teknik analisis yang dapat dilakukan adalah dengan menggunakan rasio keuangan. Salah satu rasio yang digunakan adalah rasio profitabilitas. Profitabilitas merupakan rasio keuangan yang digunakan untuk mengukur kemampuan perusahaan dalam menghasilkan laba. Mas'ud dan Srengga (2012) menemukan bahwa profitabilitas secara negatif berpengaruh signifikan terhadap financial distress. Artinya, semakin rendah profitabilitas suatu perusahaan, maka semakin tinggi pula peluang terjadinya financial distress.

Leverage merupakan rasio yang digunakan untuk mengetahui berapa jumlah aset perusahaan yang dibiayai dari hutang. Hidayat dan Meiranto (2014) mengatakan jika total hutang perusahaan terlalu besar, maka akan mengakibatkan suatu perusahaan semakin rawan terhadap financial distress. Hal ini sejalan dengan penelitian yang dilakukan oleh Rohmadini, et al (2018) yang menemukan bahwa leverage dapat digunakan untuk memprediksi financial distress.

Untuk memprediksi financial distress bisa digunakan rasio likuiditas, di mana untuk mengetahui kemampuan perusahaan dalam melunasi kewajiban jangka pendeknya. Pada penelitian Widhiari dan Merkusiwati (2015) ada pengaruh antara likuiditas dengan financial distress. Karena semakin rendah likuiditas perusahaan berakibat perusahaan dapat berada dalam kondisi financial distress .

Semakin dini kemungkinan terjadinya financial distress dapat terdeteksi, maka kebangkrutan dapat dihindari. Oleh karena itu, penelitian ini bertujuan untuk menguji pengaruh dari profitabilitas, leverage, dan likuiditas terhadap financial distress. Dengan adanya penelitian ini, diharapkan dapat memberikan gambaran bagaimana financial distress dapat dideteksi sejak dini sehingga 
tindakan-tindakan perbaikan dapat segera diambil dan kebangkrutan bisa dihindari.

\section{KERANGKA TEORITIS DAN PENGEMBANGAN HIPOTESIS}

Konflik kepentingan antara agen dan prinsipal dapat dijelaskan melalui teori keagenan. Konflik kepentingan terjadi ketika manajer sebagai agen dan investor sebagai prinsipal tidak selalu memiliki kepentingan yang sejalan. Masing-masing pihak akan memaksimalkan keuntungannya sendiri. Jensen dan Meckling (1976) mengatakan jika kedua belah pihak sama-sama ingin memaksimalkan kepentingannya masing-masing, maka terdapat alasan yang kuat untuk percaya bahwa agen tidak akan selalu bertindak sesuai dengan keinginan prinsipal. Hal ini dapat menimbulkan masalah keagenan.Untuk mengurangi masalah keagenan ini, diperlukan biaya yang disebut dengan agency cost. Pada saat terjadi financial distress, konflik kepentingan ini akan semakin besar dan menyebabkan agency cost yang harus ditanggung oleh perusahaan.

\section{Pengaruh Profitabilitas terhadap Financial Distress}

Kristanti et al (2016) mengatakan profitabilitas mencerminkan kemampuan perusahaan untuk pulih dari kondisi financial distress. Oleh karena itu, semakin tinggi tingkat profitabilitas suatu perusahaan, maka akan semakin kecil pula risiko perusahaan dalam menghadapi kebangkrutan. Hal ini sejalan dengan apa yang ditemukan oleh Christine et al (2019) yang menemukan adanya pengaruh yang signifkan dari proifitabilitas. Selain itu, Mas'ud dan Srengga (2012) juga menemukan bahwa semakin rendah profitabilitas suatu perusahaan, maka semakin tinggi pula peluang terjadinya financial distress. Oleh karena itu, hipotesis pertama dalam penelitian ini adalah sebagai berikut:

H1: Profitabilitas berpengaruh signifikan terhadap financial distress

\section{Pengaruh Leverage terhadap Financial Distress}

Leverage dapat meningkatkan risiko kebangkrutan. Damodaran (2015:314) mengatakan kemungkinan terjadinya kebangkrutan sedikit meningkat ketika perusahaan meminjam lebih banyak uang, terlepas dari seberapa besar arus kas mereka, dan peningkatan tersebut akan lebih besar untuk perusahaan dengan bisnis yang lebih berisiko. Ketika berhutang, perusahaan diwajibkan untuk membayar bunga dan pokok pinjaman. Dalam kondisi sangat sulit, di mana laba perusahaan terus menurun atau bahkan mengalami kerugian terus-menerus, perusahaan mungkin tidak dapat membayar hutangnya. Ketika perusahaan tersebut tidak dapat memenuhi kewajibannya, maka akan meningkatkan kemungkinan terjadinya financial distress.

Hal ini sejalan dengan penelitian yang dilakukan oleh Rohmadini, et al pada tahun 2018 yang menemukan bahwa terdapat pengaruh yang signifikan dari leverage terhadap financial distress. Hal ini juga didukung dengan penelitian yang dilakukan oleh Noviandri (2014) yang menemukan bahwa leverage mempengaruhi financial distress dan juga penelitian yang dilakukan oleh Hidayat 
dan Meiranto (2014) yang menemukan bahwa semakin tinggi leverage, maka suatu perusahaan akan lebih rentan mengalami financial distress.

$\mathrm{H} 2$ : Leverage berpengaruh terhadap financial distress

\section{Pengaruh Likuiditas terhadap Financial Distress}

Ross et al (2013:22) mengatakan kemungkinan perusahaan terhindar dari financial distress berhubungan dengan likuiditasnya. Semakin likuid suatu perusahaan, maka risiko menghadapi financial distress semakin kecil. Hal ini sejalan dengan apa yang ditemukan oleh Widhiari dan Merkusiwati (2015) menemukan pengaruh antara likuiditas dengan financial distress. Semakin rendah likuiditas perusahaan maka peluang perusahaan untuk berada dalam kondisi financial distress semakin tinggi. Oleh karena itu, hipotesis ketiga dalam penelitian ini adalah sebagai berikut:

H3: Likuiditas berpengaruh signifikan terhadap financial distress

\section{METODE RISET}

Populasi yang digunakan dalam penelitian ini adalah perusahaan pada sub sektor transportasi yang terdaftar di Bursa Efek Indonesia periode 2014-2019. Teknik pengambilan sampel yang digunakan dalam penelitian ini adalah purposive sampling. Berdasarkan seleksi sampel, diperoleh 11 perusahaan yang memenuhi kriteria sehingga diperoleh 66 data pengamatan. Kriteria yang digunakan dalam pemilihan sampel adalah sebagai berikut:

1. Perusahaan transportasi yang terdaftar di Bursa Efek Indonesia periode 2014-2019

2. Perusahaan yang memiliki data perusahaan yang lengkap periode 20142019

3. Perusahaan yang menggunakan Rupiah dalam laporan keuangannya

\section{Operasional Variabel}

\section{Financial Distress}

Variabel dependen dalam penelitian ini adalah financial distress. Financial Distress merupakan suatu kondisi di mana perusahaan mengalami kesulitan keuangan. Financial distress terjadi sebelum perusahaan mengalami kebangkrutan. Biasanya, perusahaan dinyatakan pailit setelah sebelumnya mengalami kerugian berturut-turut. Elloumi dan Gueyie (2001) dalam Carolina et al (2017) mengkategorikan suatu perusahaan mengalami financial distress jika mempunyai laba bersih negatif selama dua tahun berturut-turut. Oleh karena itu, dalam penelitian ini perusahaan dikatakan mengalami financial distress jika mengalami kerugian atau laba negatif selama dua tahun beruturut-turut. Penentuan tahun dilihat dari tahun pada periode pengamatan $(\mathrm{t})$ dan satu tahun sebelum periode pengamatan ( $\mathrm{t}-1)$. Perusahaan yang mengalami financial distress diberikan skor 1 (satu) dan untuk perusahaan yang tidak mengalami financial distress akan diberikan skor 0 (nol). 


\section{Profitabilitas}

Profitabilitas merupakan kemampuan suatu perusahaan dalam menghasilkan laba dan merupakan suatu alat ukur dalam menilai kemampuan manajer dalam mengelola aset perusahaan secara efektif. Penelitian ini akan menggunakan Return on Asset (ROA) dalam mengukur profitabilitas perusahaan. Rumus ROA adalah sebagai berikut:

\section{Leverage}

$$
\text { Return on Asset }=\frac{\text { Net Income }}{\text { Total Asset }}
$$

Leverage merupakan pembiayaan atas aset yang berasal dari utang. Leverage dapat menunjukkan tingkat risiko yang dihadapi oleh perusahaan. Dalam penelitian ini, leverage diukur dengan menggunakan rumus Debt to Asset Ratio yang dapat dirumuskan sebagai berikut:

$$
\text { Debt to Asset Ratio }=\frac{\text { Total Debt }}{\text { Total Asset }}
$$

\section{Likuiditas}

Menurut Rahayu dan Sopian (2017) Likuiditas menunjukkan kemampuan suatu entitas dalam menutupi kewajiban lancar perusahaan dengan memanfaatkan aset lancarnya. Penelitian ini menggunakan current ratio dalam mengukur likuiditas suatu perusahan. Rasio ini mengukur kemampuan perusahaan dalam melunasi kewajiban jangka pendeknya. Atau dengan kata lain, kemampuan aset lancar perusahaan dalam menutupi utang perusahaan yang akan jatuh tempo dalam waktu dekat. Current ratio dapat dirumuskan sebagai berikut:

$$
\text { Current Ratio }=\frac{\text { Current Asset }}{\text { Current Liabilities }}
$$

\section{Model Penelitian.}

Penelitian ini menggunakan regresi logistik dengan model penelitian sebagai berikut:

Atau

$$
\operatorname{Ln}[\operatorname{odss}(S \mid X 1, X 2, X 3, X 4)]=\mathrm{b} 0+\mathrm{b}_{1} \mathrm{X}_{1}+\mathrm{b}_{2} \mathrm{X}_{2}+\mathrm{b}_{3} \mathrm{X}_{3}+\varepsilon
$$

$$
\operatorname{Ln} \frac{P}{1-P}=\mathrm{b} 0+\mathrm{b}_{1} \mathrm{X}_{1}+\mathrm{b}_{2} \mathrm{X}_{2}+\mathrm{b}_{3} \mathrm{X}_{3}+\varepsilon
$$

Dimana:

$$
\text { Odds }\left(\mathrm{S} \mid \mathrm{X}_{1}, \mathrm{X}_{2}, \mathrm{X}_{3}\right)=\frac{P}{1-P}
$$

Keterangan:

$\mathrm{P} \quad$ : Probabilitas perusahaan mengalami financial distress dengan variabel bebas X1,X2,X3

b0 : Konstanta (nilai $\mathrm{Y}$ apabila $\mathrm{X}_{1}, \mathrm{X}_{2}, \mathrm{X}_{3}=0$ )

$b_{1} \ldots b_{3}:$ Koefisien regresi masing-masing variabel independen (nilai peningkatan atau penurunan) 


$\begin{array}{ll}\mathrm{X}_{1} & \text { : Profitabilitas } \\ \mathrm{X}_{2} & \text { : Leverage } \\ \mathrm{X}_{3} & \text { : Likuiditas } \\ \mathrm{E} & : \text { Error }\end{array}$

\section{ANALISIS DATA DAN PEMBAHASAN}

\section{Statistik Deskriptif}

\section{Tabel 1: Statistik Deskriptif}

\begin{tabular}{|ll|r|r|r|r|r|r|}
\hline & $\begin{array}{c}\text { Financial } \\
\text { Distress }\end{array}$ & Profitabilitas & Leverage & Likuiditas & $\begin{array}{c}\text { Valid N } \\
\text { (listwise) }\end{array}$ \\
\hline $\mathrm{N}$ & Statistic & 66 & 66 & 66 & 66 & 66 \\
\hline Range & Statistic & 1 & 3.387 & 8.233 & 6.034 & \\
\hline Minimum & Statistic & 0 & -1.195 & .075 & .004 & \\
\hline Maximum & Statistic & 1 & 2.192 & 8.308 & 6.038 & \\
\hline $\begin{array}{l}\text { Mean } \\
\text { Std. } \\
\text { Deviation }\end{array}$ & Statistic & .29 & -.00776 & .88918 & 1.28485 & \\
\hline
\end{tabular}

Sumber: Data diolah SPSS 24

Jumlah sampel untuk keempat variabel, yakni financial distress, profitablitas, leverage, dan likuiditas adalah enam puluh enam. Data yang valid untuk diolah juga berjumlah enam puluh enam. Berdasarkan tabel di atas, dapat diketahui nilai range, minimum, maksimum, mean dan standar deviasi dari setiap variabel.

\section{Menilai Model Fit}

Menilai model fit dilakukan untuk menilai overall fit model terhadap data. Hipotesis untuk menilai model fit adalah :

Ho : Model yang dihipotesiskan fit dengan data

Ha : Model yang dihipotesiskan tidak fit dengan data

Hasil analisis dari penilaian model fit adalah sebagai berikut:

Tabel 2: -2Loglikelihood Konstanta

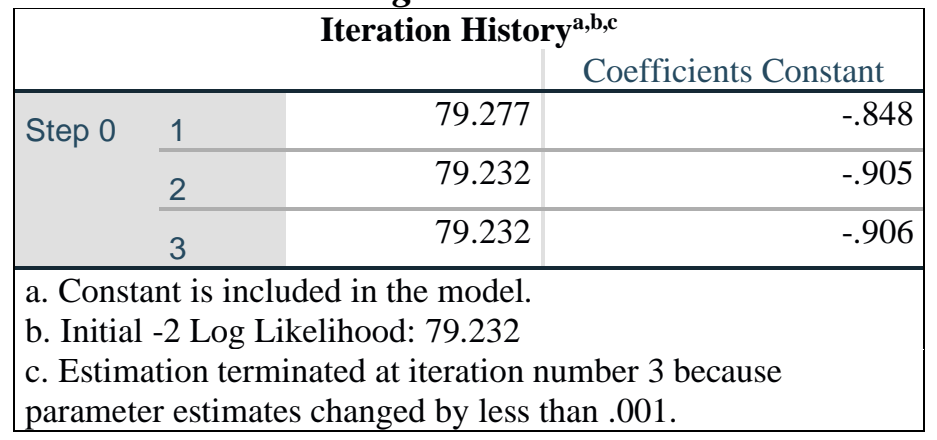

Sumber: Data diolah SPSS 24 
Tabel 3: -2Loglikelihood Konstanta dan Variabel Bebas

\begin{tabular}{|c|c|c|c|c|c|c|}
\hline \multicolumn{7}{|c|}{ Iteration History $^{\mathrm{a}, \mathrm{b}, \mathbf{c}, \mathbf{d}}$} \\
\hline \multirow[b]{2}{*}{ Iteration } & & \multirow{2}{*}{$\begin{array}{c}-2 \log \\
\text { likelihood }\end{array}$} & \multicolumn{4}{|c|}{ Coefficients } \\
\hline & & & Constant & $\mathrm{X} 1$ & $\mathrm{X} 2$ & $\mathrm{X} 3$ \\
\hline \multirow[t]{9}{*}{ Step 1} & 1 & 65.393 & -.864 & -2.289 & .069 & -.050 \\
\hline & 2 & 50.108 & -1.211 & -7.009 & -.047 & .038 \\
\hline & 3 & 38.034 & -1.463 & -15.119 & -.297 & .119 \\
\hline & 4 & 30.789 & -1.329 & -25.632 & -1.208 & .104 \\
\hline & 5 & 28.887 & -1.333 & -34.287 & -1.871 & .089 \\
\hline & 6 & 28.713 & -1.386 & -37.908 & -2.109 & .084 \\
\hline & 7 & 28.711 & -1.398 & -38.384 & -2.138 & .084 \\
\hline & 8 & 28.711 & -1.398 & -38.392 & -2.138 & .084 \\
\hline & 9 & 28.711 & -1.398 & -38.392 & -2.138 & .084 \\
\hline
\end{tabular}

a. Method: Enter

b. Constant is included in the model.

c. Initial -2 Log Likelihood: 79.232

d. Estimation terminated at iteration number 9 because parameter estimates changed by less than .001 .

Sumber: Data diolah SPSS 24

Dari hasil pengujian di atas dapat dilihat bahwa nilai -2Loglikelihood untuk model dengan dengan konstanta saja adalah 79,232. Nilai tersebut dibandingkan dengan nilai chi square tabel dengan $\mathrm{df}(\mathrm{n}-1)=65$ dan signifikansi 0,05 adalah 84,821 . Ini berarti nilai 79,232 < 84,821 sehingga menerima Ho. Artinya, model dengan konstanta saja sudah fit dengan data. Nilai -2Loglikelihood untuk model dengan konstanta dan variabel bebas adalah 28,711. Nilai ini dibandingkan dengan nilai chi square tabel dengan df $(n-3-1)=62$ dengan signifikansi 0,05 adalah sebesar 81,381 . Ini berarti 28,711 <81,381, artinya model dengan variabel bebas fit dengan data sehingga model ini layak untuk dipergunakan.

Selain itu, statistik ini dapat digunakan untuk menentukan apakah dengan ditambahkanya variabel bebas akan secara signifikan memperbaiki model fit. Selisihnya, dapat dilihat melalui tabel omnibus test berikut:

Tabel 4: Omnibus Test

\begin{tabular}{|llr|r|r|}
\hline \multicolumn{5}{|c|}{ Omnibus Tests of Model Coefficients } \\
& & Chi-square & df & Sig. \\
\hline Step 1 & Step & 50.521 & 3 & .000 \\
\cline { 2 - 5 } & Block & 50.521 & 3 & .000 \\
\cline { 2 - 5 } & Model & 50.521 & 3 & .000 \\
\hline
\end{tabular}

Sumber: Data diolah SPSS 24

Berdasarkan tabel di atas, terdapat selisih sebesar 50,521 (79,232-28,711). Nilai ini dibandingkan dengan chi square tabel dengan df (selisih df kedua model) $=3$ dan signifikansi 0,05 sebesar 7,815. Oleh karena 50,521 lebih besar dari tabel maka dapat dikatakan bahwa selisih penurunannya signifikan. Hal ini berarti penbambahan variabel bebas kedalam model memperbaiki fit data.

Selain itu, Berdasarkan tabel di atas, diketahui nilai Chi-Square sebesar 50,521 memiliki tingkat signifikansi sebesar 0,000 dimana 0,000<0,05. Hal ini 
mengindaksikan adanya pengaruh simultan variabel independen terhadap financial distress. Artinya, profitabilitas, leverage dan likuiditas secara simultan berpengaruh terhadap financial distress.

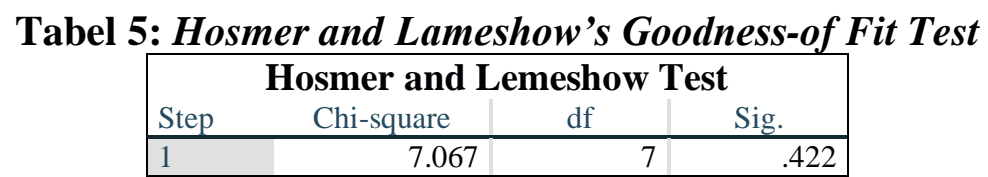

Sumber: Data diolah SPSS 24

Hasil pengujian di atas menunjukkan bahwa nilai sig dari Hosmer and Lemeshow test adalah $0,422(0,422>0,05)$ yang berarti hipotesis nol tidak dapat ditolak sehingga dapat disimpulkan bahwa model mampu meprediksi nilai observasinya atau dapat dikatakan model dapat diterima karena cocok dengan data observasinya.

\begin{tabular}{|c|c|c|c|}
\hline \multicolumn{4}{|c|}{ Model Summary } \\
\hline Step & -2 Log likelihood & $\begin{array}{c}\text { Cox \& Snell R } \\
\text { Square }\end{array}$ & $\begin{array}{c}\text { Nagelkerke R } \\
\text { Square }\end{array}$ \\
\hline 1 & $28.711^{\mathrm{a}}$ & .535 & .765 \\
\hline
\end{tabular}

Dari hasil pengujian di atas diketahui nilai Cox and Snell's $R$ Square sebesar 0,535 dan nilai Nagelkerke $R$ Square adalah 0,765 yang berarti variabilitas variabel dependen yang dapat dijelaskan oleh variabilitas variabel independen sebesar $76,5 \%$. Sedangkan sisanya sebesar $23,5 \%$ dapat dijelaskan dengan variabel lain.

Tabel 7: Tabel klasifikasi 2 X 2

\begin{tabular}{|c|c|c|c|c|c|}
\hline \multicolumn{6}{|c|}{ Classification Table $^{a}$} \\
\hline & \multirow{3}{*}{\multicolumn{2}{|c|}{ Observed }} & \multicolumn{3}{|c|}{ Predicted } \\
\hline & & & \multicolumn{2}{|c|}{ Financial Distress } & \multirow[b]{2}{*}{$\begin{array}{l}\text { Percentage } \\
\text { Correct }\end{array}$} \\
\hline & & & $\begin{array}{c}\text { Tidak Financial } \\
\text { Distress }\end{array}$ & $\begin{array}{l}\text { Financial } \\
\text { Distress }\end{array}$ & \\
\hline \multirow[t]{3}{*}{ Step 1} & \multirow[t]{2}{*}{$\begin{array}{l}\text { Financial } \\
\text { Distress }\end{array}$} & $\begin{array}{l}\text { Tidak Financial } \\
\text { Distress }\end{array}$ & 43 & 4 & 91.5 \\
\hline & & Financial Distress & 4 & 15 & 78.9 \\
\hline & \multicolumn{2}{|c|}{ Overall Percentage } & & & 87.9 \\
\hline
\end{tabular}

Dari hasil output di atas dapat dilihat bahwa prediksi perusahaan yang tidak mengalami financial distress adalah 47 pengamatan dan berdasarkan observasi, perusahaan yang benar-benar tidak mengalami financial distress adalah 43 pengamatan sehingga ketepatan klasifikasi adalah 91,5\% (43/47). Prediksi perusahaan yang mengalami financial distress adalah 19 dan berdasarkan observasi perusahaan yang benar-benar mengalami financial distress adalah 15 sehingga ketepatan prediksi 78,9\% (15/19). Secara keseluruhan ketepatan 
klasifikasi adalah 87,9\% sehingga bisa dikatakan model ini memiliki ketepatan yang cukup tinggi dalam memprediksi financial distress.

\section{Pengujian Hipotesis}

Tabel 8: Pengujian Hipotesis

\begin{tabular}{|c|c|c|c|c|c|c|c|}
\hline \multicolumn{8}{|c|}{ Variables in the Equation } \\
\hline & & $\mathrm{B}$ & S.E. & Wald & df & Sig. & $\operatorname{Exp}(B)$ \\
\hline \multirow[t]{4}{*}{ Step $1^{\mathrm{a}}$} & Profitabilitas & -38.392 & 10.330 & 13.813 & 1 & .000 & .000 \\
\hline & Leverage & -2.138 & 1.003 & 4.543 & 1 & .033 & .118 \\
\hline & Likuiditas & .084 & .402 & .044 & 1 & .834 & 1.088 \\
\hline & Constant & -1.398 & 1.130 & 1.529 & 1 & .216 & .247 \\
\hline
\end{tabular}

a. Variable(s) entered on step 1: Profitabilitas, Leverage, Likuiditas.

Dari Tabel di atas, diperoleh persamaan sebagai berikut:

$$
\operatorname{Ln} \frac{P}{1-P}=-1,398-38,392 \mathrm{X}_{1}-2,138 \mathrm{X}_{2}+0,084_{3} \mathrm{X}_{3}+\varepsilon
$$

Atau

Dimana:

$$
\begin{aligned}
\frac{P}{1-P} & =\mathrm{e}^{(-1,398-38,392 \mathrm{X} 1-2,138 \mathrm{X} 2+0,084 \mathrm{X} 3+\varepsilon)} \\
& =\mathrm{e}^{-1,398} \mathrm{Xe}^{-38,392 \mathrm{X} 1} \mathrm{Xe}^{-2,138 \mathrm{X} 2} \mathrm{Xe}^{0,084 \mathrm{X} 3}+\varepsilon
\end{aligned}
$$

$$
\mathrm{e}=\text { Bilangan eksponensial }
$$

Keterangan:

$\mathrm{P} \quad$ : Probabilitas perusahaan mengalami financial distress dengan variabel bebas X1,X2,X3

b0 : Konstanta (nilai $Y$ apabila $\mathrm{X}_{1}, \mathrm{X}_{2}, \mathrm{X}_{3}=0$ )

$b_{1} \ldots b_{3}$ : Koefisien regresi masing-masing variabel independen (nilai peningkatan atau penurunan)

$\mathrm{X}_{1} \quad$ : Profitabilitas

$\mathrm{X}_{2} \quad$ : Leverage

$\mathrm{X}_{3} \quad$ : Likuiditas

E : Error

Pengaruh dari variabel dependen terhadap variabel independen, yakni financial distress, dapat dijelaskan sebagai berikut:

a) Nilai statistik Wald untuk variabel profitabilitas adalah 13,813 dengan nilai sig sebesar $0,000 \quad(0,00<0,05)$, maka $\mathrm{H} 1$ diterima yang berarti profitabilitas memiliki pengaruh yang signifikan terhadap financial distress.

b) Nilai statistik Wald untuk variable leverage adalah 4,543dengan nilai sig sebesar $0,033(0,033<0,05)$, maka $\mathrm{H} 3$ diterima yang berarti leverage memiliki pengaruh yang signifikan terhadap financial distress.

c) Nilai statistik Wald untuk variable likuiditas adalah 0,044 dengan nilai sig sebesar $0,834(0,834>0,05)$, maka H3 ditolak yang berarti likuiditas tidak memiliki pengaruh yang signifikan terhadap financial distress.

\section{Interpretasi Hasil Penelitian}




\section{Pengaruh Profitabilitas terhadap Financial Distress}

Hasil pengujian hipotesis menunjukkan bahwa profitabilitas berpengaruh signifikan terhadap financial distress. Hasil ini konsisten dengan penelitian yang dilakukan oleh Mas'ud dan Srengga (2012) serta Christine, et al (2019) yang menemukan bahwa profitabilitas memiliki pengaruh yang siginfikan terhadap financial distress. Namun, hasil penelitian ini tidak sejalan dengan penelitian yang dilakukan oleh Rohmadini, et al (2018) dan Santoso, et al (2018) yang tidak menemukan bukti adanya pengaruh siginifikan dari profitabilitas.

Hasil pengujian juga menunjukkan bahwa profitabilitas memiliki pengaruh negatif terhadap financial distress. Artinya, semakin rendah tangkat profitabilitas suatu perusahaan, semakin tinggi pula peluang untuk terjadinya financial distress. Menurut Kazemian, et al (2017) profitabilitas yang rendah merupakan suatu sinyal bahwa perusahaan tidak mempu mengubah arus kas masuk menjadi keuntungan. Oleh karena itu, semakin tinggi profitabilitas, semakin rendah pula kemungkinan suatu perusahaan mengalami financial distress. Selain itu, sama seperti penelitian ini, Kazemian, et al (2017) juga menemukan adanya pengaruh negatif dari profitabilitas terhadap financial distress.

\section{Pengaruh leverage terhadap Financial Distress}

Berdasarkan pengujian hipotesis, diketahui bahwa leverage memiliki pengaruh yang signifikan terhadap financial distress. Hasil ini sejalan dengan penelitian yang dilakukan oleh Rohmadini, et al (2018), Noviandri (2014), dan Hidayat dan Meiranto (2014). Hasil penelitian ini tidak sejalan dengan penelitian yang dilakukan oleh Yanuar (2018) serta Rahayu dan Sopian (2017) yang tidak menemukan bukti bahwa leverage berpengaruh terhadap financial distress.

Umumnya, semakin tinggi tingkat leverage suatu perusahaan, maka semakin besar kemungkinan untuk terjadi financial distress. Akan tetapi, hasil uji hipotesis dalam penelitian ini menunjukkan bahwa leverage memiliki pengaruh negatif terhadap financial distress. Arah hubungan negative ini juga ditemui pada penelitian yang dilakukan oleh Kristanti, et al (2016), Pandegirot, et al (2019), Masdupi, et al (2018) dan Alifiah (2014). Artinya, semakin tinggi tingkat leverage suatu perusahaan, semakin rendah pula kemungkinan untuk terjadinya financial distress.

Masdupi, et al (2018) mengatakan bahwa penggunaan utang dapat meningkatkan nilai perusahaan dan mengurangi financial distress. Lebih lanjut Masdupi et al (2018) juga mengatakan hubungan yang negatif ini nenandakan bahwa perusahaan dapat mengelola utang dengan baik sehingga dapat meningkatkan profitabilitas perusahaan dan terhindar dari financial distress.

Ross, et al (2013:931) mengatakan financial distress dapat digunakan sebagai sistem peringatan dini untuk suatu masalah. Perusahaan dengan tingkat utang yang lebih tinggi akan mengalami financial distress lebih awal daripada perusahaan dengan tingkat utang yang rendah. Akan tetapi, perusahaan yang mengalami financial distress lebih awal akan memiliki waktu lebih lama untuk memperbaiki keadaan dan melakukan reorganisasi. Perusahaan dengan tingkat leverage yang rendah akan mengalami financial distress kemudian, dan dalam banyak kasus, terpaksa harus dilikuidasi. 


\section{Pengaruh Likuiditas terhadap Financial Distress}

Berdasarkan hasil pengujian, tidak ditemukan adanya pengaruh dari likuiditas terhadap financial distress. Hasil ini sejalan dengan penelitian yang dilakukan oleh Andriyani, et al (2018) dan Santoso, et al (2018) namun tidak sejalan dengan penelitian yang dilakukan oleh Widhiari dan Merkusiwati (2015).

Hasil ini menunjukkan bahwa pada perusahaan transportasi, tingkat likuiditas tidak memiliki perbedaan yang signifikan antara perusahaan yang mengalami financial distress dan tidak mengalami financial distress. Rahayu dan Sopian (2017) mengatakan hasil yang tidak siginfikan dapat terjadi karena perusahaan sampel memilki kemampun untuk memenuhi kewajiban jangka pendeknya Artinya perusahaan mampu menutupi kewajiban jangka pendek dengan aset lancar yang dimiliki sehingga perusahaan dapat membayar kewajibannya tepat waktu.

\section{KESIMPULAN DAN SARAN}

Berdasarkan hasil penelitian ini, maka dapat disimpulkan bahwa:

1) Profitabilitas secara negatif mempengaruhi financial distress. Hal ini berarti semakin tinggi profitabilitas suatu perusahaan, maka semakin rendah kemungkinan terjadinya financial distress. Tingkat profitabilitas yang tinggi mengindikasikan perusahaan mampu memaksimalkan asetnya untuk memperoleh keuntungan sehingga financial distress dapat dihindari.

2) Leverage secara negatif mempengaruhi financial distress. Artinya, semakin tinggi tangkat leverage suatu perusahaan, maka kemungkinan untuk terjadinya financial distress semakin rendah. Hal ini berarti perusahaan mampu mengelola utangnya dengan baik dan dapat menghasilkan keuntungan sehingga perusahaan dapat terhindar dari financial distress.

3) Likuiditas tidak memiliki pengaruh yang signifikan terhadap financial distress. Hal ini terjadi karena likuiditas dari sampel perusahaan yang digunakan dalam penelitian ini tidak berbeda jauh antara perusahaan yang mengalami financial distress dan tidak mengalami financial distress.

Penelitian ini diharapkan mampu menambah khasanah ilmu dan pengetahuan yang terkait dengan financial distress. Dalam penelitian ini juga masih terdapat hasil penelitain yang tidak konsisten dengan hasil penelitian sebelumnya sehingga penelitian mengenai financial distress masih dapat dikembangkan. Untuk penelitian selanjutnya diharapkan untuk:

a) Menggunakan sektor lain selain sektor transportasi. Hasil berbeda mungkin didapatkan pada sektor lain karena tiap jenis perusahaan memiliki karakter yang berbeda. 
b) Menambah jumlah tahun pengamatan. Diharapkan dengan bertambahnya jumlah tahun pengamatan akan membuat hasil penelitian akan lebih mencerminkan kondisi sesungguhnya.

c) Menambah variabel lain seperti ukuran perusahaan, good coorporate governance, dan pertumbuhan.

\section{DAFTAR PUSTAKA}

Alifiah, Mohd Norfian. 2013. Prediction of financial distress companies in the trading and services sector in Malaysia using macroeconomic variables. Procedia - Social and Behavioral Sciences. 129. $90-98$.

Carolina, Verani, Elyzabet I. Marpaung, dan Derry Pratama. (2017). Analisis Rasio Keuangan untuk Memprediksi Kondisi Financial Distress (Studi Empiris pada Perusahaan Manufaktur yang Terdaftar di Bursa Efek Indonesia Periode 2014-2015). Jurnal Akuntansi Maranatha. Vol 9, hal 137-145.

Christine, Debby, Jessica Wijaya, Kevin Chandra, Mia Pratiwi, Mahmuddin Syah Lubis, S.E., M.Si,dan Isna Asdiani Nasution, S.Sos., M.I.Kom.(2019). Pengaruh Profitabilitas, Leverage, Total Arus Kas dan Ukuran Perusahaan terhadap Financial Distress pada Perusahaan Property dan Real Estate yang Terdaftar di Bursa Efek Indonesia Tahun 2014-2017. Jurnal Ekonomi \& Ekonomi Syariah. Vol 2, hal 340-351

Damodaran, Aswath. (2015). Applied Corporate Finance. $4^{\text {th }}$ Edition. John Wiley $\&$ Sons, Inc.

Hapsari, Evanny Indri. (2012). Kekuatan Rasio Keuangan dalam Memprediksi Kondisi Financial Distress Perusahaan Manufaktur di BEI. Jurnal Dinamika Manajemen. Vol 3, hal 101-109

Hidayat, Arif Muhammad dan Wahyu Meiranto. (2014). Prediksi Financial distress perusahaan manufaktur di Indonesia. Diponegoro Journal of Accounting. Vol 3, hal 1-11

Jensen, Michael. C. Dan William H. Meckling. (1976). Theory of the Firm: Managerial Behaviour, Agency Cost and Ownership Structure. Journal of Financial Economics, Vol. 3 Oktober, Hal 305-360.

Kazemian, Soheil, Noor Azura Ahmad Shauri, Zuraidah Mohd Sanusi, Amrizah Kamaluddin, Shuhaida Mohamed Shuhidan. (2017). Monitoring mechanisms and financial distress of public listed companies in Malaysia. Journal of International Studies, Vol 1, hal 92-109 
Kristianti, Farida Titik, Sri Rahayu, dan Akhmad Nurul Huda. (2016). The Determinant of Financial Distress on Indonesia Family Firm. ProcediaSocial Behavioral Sciences. 219. Hlm: 440-447.

Masdupi, Erni, Abel Tasman, dan Atri Davista. (2018). The Influence of Liquidity, Leverage and Profitability on Financial Distress of Listed Manufacturing Companies in Indonesia. Advances in Economics, Business and Management Research. Vol 57, hal 223-228

Mas'ud, Imam dan Reva Masmi Srengga. (2012). Pengaruh Rasio Keuangan untuk Memprediksi Fnancial Distress perusahaan manufaktur yang terdaftar di bursa efek indonesia. Jurnal akuntansi Universitas Jember. Vol 10, hal 139-154

Noviandri, Tio. (2014). Peranan Analisis Rasio Keuangan dalam Memprediksi Kondisi Financial Distress Perusahaan Sektor Perdagangan. Jurnal Ilmu Manajemen. Vol 2, hal 1655-1665

Pandegirot, Sonia Ch. G., Paulina Van Rate, dan Joy E. Tulung. (2019). Analisis Pengaruh Current Ratio, Institutional Ownership, Debt to Asset Ratio terhadap Kondisi Financial Distress pada Perusahaan Property dan Real Estate di Bursa Efek Indonesia 2013-2017. Jurnal EMBA. Vol 7. No. 8., hal 3339-3348

Rahayu, Wiwin Putri dan Dani Sopian. (2017). Pengaruh Rasio Keuangan dan Ukuran Perusahaan terhadap Financial Distress (Studi Empiris pada Perusahaan Food and Beverage di Bursa Efek Indonesia. Competitive. Vol 1.

Rohmadini, Alfinda, Muhammad Saifi, dan Ari Darmawan. (2018). Pengaruh Profitabilitas, Likuiditas, dan Leverage terhadap financial distress. Jurnal Administrasi Bisnis (JAB). Vol 61, hal 11-19.

Ross, Stephen A., Randolph W. Westerfield, dan Jeffrey Jaffe. (2013). Coorporate Finance. Edisi 10. New York.: Mcgraw-Hill/Irwin

Santoso, Githa Ayu Pradewi, Yulianeu, Aziz Fathoni. (2018). Analysis of Effect of Good Corporate Governance, Financial Performance and Firm Size on Financial Distress in Property and Real Estate Company Listed Bei 20122016. Journal of Management. Vol 4.

Widhiari, Ni Luh Made Ayu dan Ni K. Lely Aryani Merkusiwati. (2015). Pengaruh Rasio Likuiditas, Leverage, Operating Capacity dan Sales Growth terhadap Financial Dsitress. E-Jurnal Akuntansi Universitas Udayana. Vol 11, hal 456-469

Widyasaputri, Erlindasari. (2012). Analisis Mekanisme Corporate Governance pada Perusahaan yang Mengalami Kondisi Financial Distress. Accounting Analysis Journal. Vol 1, hal 1-8 
Jurnal Akuntansi Berkelanjutan Indonesia - Vol. 3, No. 3, Sep 2020 - Rahma

Yanuar, Yayan. (2018). Pengaruh Rasio Likuiditas, Leverage Keuangan, Operating Income, dan Efektifitas Komite Audit terhadap Financial Distress. Scientific Journal of Reflection: Economic, Accounting, Management and Bussines. Vol. 1, hal 111-120 